\title{
Evaluarea asocierii dintre nivelul colesterolului seric, gradul de control și treapta terapeutică la copiii cu astm şi sensibilizare aeroalergenică
}

\author{
Ana-Maria Moiceanu Şovărel ${ }^{1,2}$, Eugenia Buzoianu ${ }^{1,2}$, Mariana Moiceanu², \\ Doina Anca Pleşca ${ }^{1,2}$ \\ ${ }^{1}$ Facultatea de Medicină, Universitatea de Medicină și Farmacie „Carol Davila“, București, România \\ 2Spitalul Clinic de Copii „Dr. Victor Gomoiu“, București, România
}

\begin{abstract}
REZUMAT
Astmul este o afecţiune heterogenă caracterizată prin inflamaţia cronică a căilor aeriene. Colesterolul este un factor proinflamator corelat, în unele studii cu inflamaţia din astm.

În Spitalul Clinic de Copii „Dr. Victor Gomoiu“, în perioada ianuarie 2016-septembrie 2018, a fost initiat un studiu prospectiv care a inclus 100 de copii în vârstă de 5-18 ani, diagnosticaţi cu astm alergic și sensibilizare aeroalergenică. Toţi pacienţii înrolaţi au fost monitorizaţi privind nivelul colesterolului, treapta terapeutică primită şi gradul de control al astmului.

Obiectivul studiului a fost să se evalueze dacă există o asociere între valorile colesterolului seric și controlul astmului și între colesterolul seric și treapta de tratament de control (ca indicator al severităţii astmului).

Concluzii. În lotul studiat, pacienţii încadraţi în categoriile de astm parţial controlat și necontrolat au fost în procent mai mare cu valori crescute ale colesterolului seric comparativ cu cei cu astm controlat; copiii înregistraţi în categoriile de astm moderat și sever au fost în procent mai mare cu colesterol seric total crescut faţă de cei cu astm uşor.
\end{abstract}

Cuvinte cheie: astm, control, colesterol, tratament de control

\section{INTRODUCERE}

Astmul este o afecţiune heterogenă caracterizată prin inflamaţia cronică a căilor aeriene. Colesterolul este un factor proinflamator corelat, în unele studii cu inflamaţia din astm $(1,2)$. Astmul este cea mai frecventă boală cronică a copilăriei care afectează toate grupele de vârstă și, totodată, o problemă majoră de sănătate publică în întreaga lume $(3,4)$.

Inflamația cronică a căilor respiratorii joacă un rol important în fiziopatologia astmului, alături de hiperreactivitatea bronșică $(3,4)$. Intensitatea inflamației mucoasei bronşice regăsită în astm este corelată cu factorii genetici, vârsta, factori favorizanţi (fumatul pasiv, expunerea la substanţe poluante, statusul socioeconomic), expunerea la factorii declanșatori (aeroalergeni), raspunsul la tratament și gradul de controlul al astmului.
Fenotipul de astm alergic este întâlnit la majoritatea copiilor cu astm bronşic ( $80 \%)$, în timp ce la adulţi acest fenotip se regăsește într-un procent de aproximativ 50\%. Obiectivarea sensibilizării alergenice la polenul de arbori și graminee, epitelii de animale, acarienii din praful de casă se realizează prin determinarea anticorpilor de tip imunoglobuline E și/ sau prin teste cutanate prick (4).

Există diferențe semnificative în rândul pacienților cu astm alergic în ceea ce privește dificultatea de a obține controlul bolii prin reducerea cu succes a inflamației bronșice. Multe studii au încercat să identifice cauzele care conduc la diferențe privind rezultatele terapeutice.

În opinia unor autori, valorile crescute ale colesterolului seric regăsite la pacienţii cu astm bronşic pot să aibă rol proinflamator la nivelul mucoaşei bronșice $(3,5)$. 
Hipercolesterolemia pare că se asociază cu accentuarea expresiei mecanismelor proinflamatorii, ceea ce ar determina o creștere a nivelului de citokine proinflamatorii, a moleculelor de adeziune celulară și a altor proteine plasmatice (ceruloplasmina, fibrinogenul sau alfa 1 antitripsina) implicate în sensibilizarea inflamatorie $(3,4)$.

\section{SCOPUL STUDIULUI}

Obiectivul studiului a fost de a evalua dacă există o asociere între:

- nivelul seric al colesterolului seric total și gradul de control al bolii la copiii cu astm alergic și sensibilizare aeroalergenică;

- nivelul seric al colesterolului seric total și treapta terapeutică de control (ca marker al severităţii astmului) la copiii cu astm alergic şi sensibilizare aeroalergenică.

\section{MATERIAL ŞI METODĂ}

A fost realizat un studiu prospectiv în care au fost incluși 100 copii cu vârsta cuprinsă între 5 şi 18 ani, diagnosticaţi cu astm alergic și sensibilizare aeroalergenică evaluaţi și monitorizaţi în Clinica de Pediatrie din Spitalul Clinic de Copii „Dr. Victor Gomoiu“, în perioada ianuarie 2016-septembrie 2018.

Criteriile de includere în studiu au fost: vârsta cuprinsă între 5 şi 18 ani, diagnostic de astm stabilit pe baza datelor anamnestico-clinice și a probelor funcţionale respiratorii, a spirometriei (creșterea semnificativă a FEV1 peste $12 \%$ şi peste $200 \mathrm{ml}$ faţă de valorile iniţiale după administrarea de salbutamol pe cale inhalatorie), sensibilizare aeroalergenică dovedită prin determinarea nivelului IgE specifice (Imunoglobulina E) şi/sau testare cutanată prick.

Criteriile de excludere din studiu au fost: pacienţii nonatopici, pacienţii cu alte tipuri de sensibilizare (alimentară, medicamentoasă), dislipidemii familiale.

Studiul a fost aprobat de Comitetul de Etică al Spitalului Clinic de Copii „Dr. Victor Gomoiu“. Pentru fiecare copil introdus în studiu s-a obţinut acordul scris al aparținătorilor, asigurând confidenţialitatea și protecţia asupra identităţii datelor pacienţilor.

Pentru fiecare pacient s-au evaluat controlul astmului pe baza simptomelor diurne și trezirilor nocturne datorate bolii, limitarea activităţii fizice și frecvenţa cu care s-au utilizat bronhodilatatoare cu acţiune de scurtă durată (salbutamol). În concordanță cu criteriile GINA (2019), astmul bronșic este clasificat în: astm controlat, parţial controlat și necontrolat.

De precizat că pentru fiecare pacient inclus în studiu a fost monitorizată treapta terapeutică recomandată, coroborată cu treapta de control (4).
În plus, fiecărui pacient din lotul de studiu i s-a determinat valoarea serică a colesterolului seric total, iar rezultatele au fost interpretate în conformitate $\mathrm{cu}$ „National Cholesterol Education Program's“ (NCEP's), considerând valoarea colesterolului seric total normal de $\leq 200 \mathrm{mg} / \mathrm{dl}$.

Fiecare pacient inclus în studiu a primit un plan de acţiune individualizat, care cuprindea recomandările terapeutice scrise pentru menţinerea controlului astmului (6).

În final, s-a evaluat asocierea dintre nivelul seric al colesterolului total și gradul de control al astmului, precum și asocierea dintre nivelul seric al colesterolului total şi treapta terapeutică necesară în controlul bolii.

\section{REZULTATE}

\section{Influența nivelului colesterolului total asupra gradului de control al astmului}

$44,7 \%$ dintre pacienţii pediatrici incluși în studiu au avut astm bronșic controlat și un nivel normal al colesterolului, în timp ce $3,8 \%$ dintre pacienţii cu astm controlat au înregistrat valori crescute ale colesterolului seric. Dintre cei 100 de copii astmatici incluși în studiu, 10,6\% au prezentat astm parţial controlat și un nivel normal de colesterol seric, în timp ce $43,4 \%$ dintre pacienţii cu astm parţial controlat au avut un nivel crescut al colesterolului. 52,8\% dintre cei cu astm necontrolat au avut valori crescute ale colesterolului seric. În tabelul 1 este ilustrată distribuția valorilor colesterolului în funcție de gradul de control al astmului.

Utilizând testul Chi Square pătrat pentru a analiza influenţa colesterolului seric asupra gradului de control al astmului (controlat, parțial controlat si necontrolat), a rezultat o asociere statistic semnificativă între cele două variabile $(\mathrm{p}<0,001)$. Astfel, s-a observat că un procent mai mare de pacienți care prezentau valori crescute ale colesterolului seric se încadrau în categoriile de astm parțial controlat și necontrolat comparativ cu cei diagnosticați cu astm controlat, la care procentul celor cu colesterol seric normal este mai mare. Aceste date sunt prezentate în figura 1.

\section{Influența nivelului colesterolului total asupra severității astmului}

În cazul pacienţilor care primeau terapie "controller" corespunzător cu treapta 1 de severitate sau treapta $2,25,5 \%$ au avut valori normale ale colesterolului seric, în timp ce 9,4\% dintre aceștia au înregistrat valori crescute ale colesterolului. $8,5 \%$ dintre pacienţii 
TABELUL 1. Distribuția pacienților care prezentau valori normale, respectiv crescute ale colesterolului coroborat cu gradul de control al astmului

\begin{tabular}{|c|c|c|c|c|c|c|}
\hline & \multicolumn{3}{|c|}{ Gradul de control } & \multirow{2}{*}{ Total } \\
\hline & & & Controlat & Parțial controlat & Necontrolat & \\
\hline \multirow{6}{*}{ 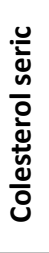 } & \multirow{2}{*}{ Normal } & Total & 21 & 5 & 21 & 47 \\
\hline & & $\%$ & $44,7 \%$ & $10.6 \%$ & $44,7 \%$ & $100,0 \%$ \\
\hline & \multirow{2}{*}{ Crescut } & Total & 2 & 23 & 28 & 53 \\
\hline & & $\%$ & $3,8 \%$ & $43,4 \%$ & $52,8 \%$ & $100,0 \%$ \\
\hline & \multirow{2}{*}{ Total } & Total & 23 & 28 & 49 & 100 \\
\hline & & $\%$ & $23,0 \%$ & $28,0 \%$ & $49,0 \%$ & $100,0 \%$ \\
\hline
\end{tabular}

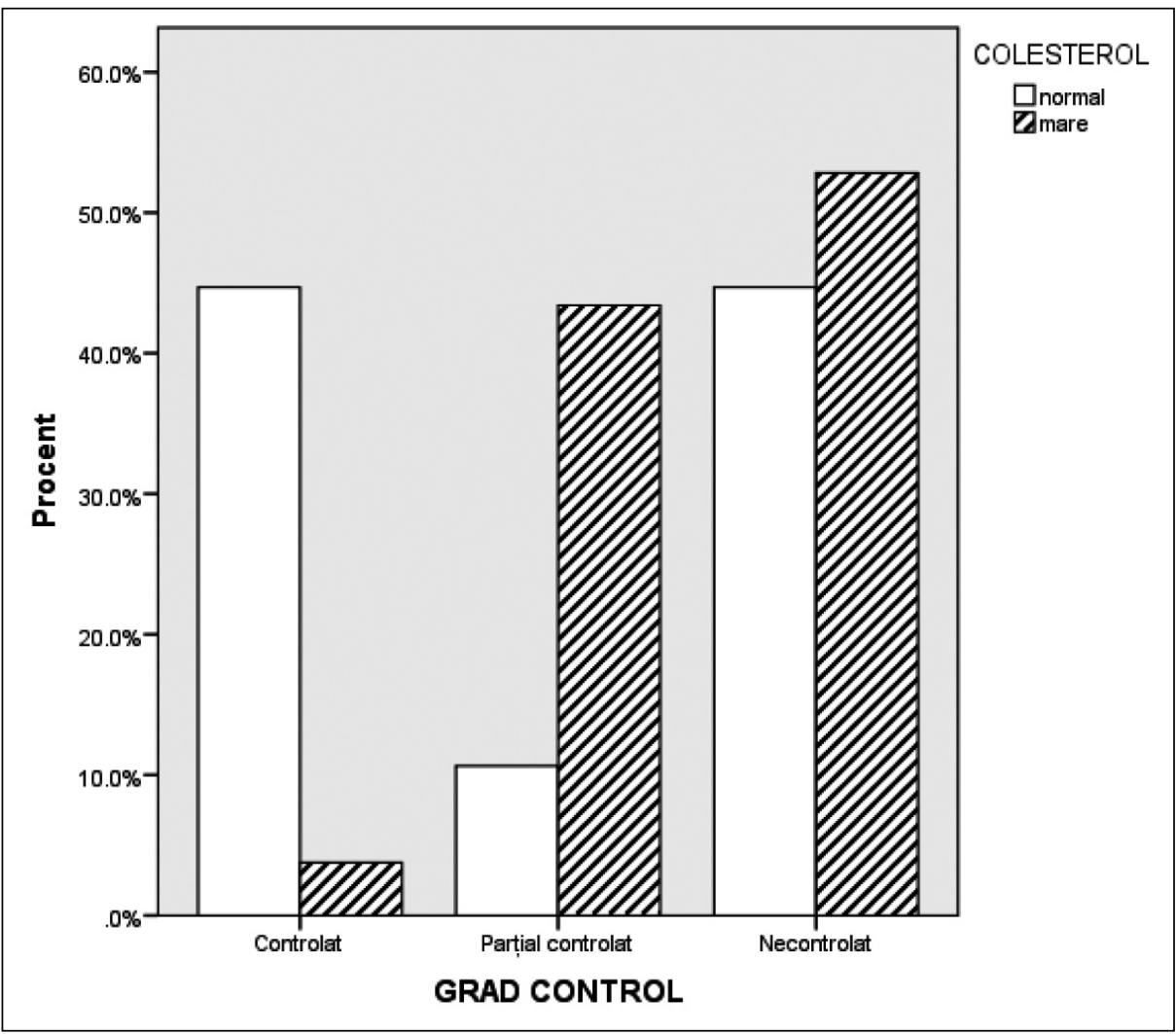

FIGURA 1. Distribuția procentuală a cazurilor care aveau valori crescute ale colesterolului total, pe cele trei categorii de control ale astmului care primeau terapie "controller" corespunzător treptei de severitate 4 au avut valori normale ale colesterolului seric, în timp ce $39,6 \%$ dintre aceștia au avut niveluri crescute ale colesterolului. Aceste rezultate sunt reunite în tabelul 2.

TABELUL 2. Distribuția cazurilor de pacienți pediatrici astmatici care prezentau valori normale respectiv crescute ale colesterolului coroborat cu treapta terapeutică

\begin{tabular}{|l|c|c|c|c|c|}
\hline \multicolumn{2}{|c|}{} & \multicolumn{3}{|c|}{ Treapta terapeutică } & \multirow{2}{*}{ Total } \\
\cline { 3 - 6 } \multicolumn{2}{|c|}{} & $\mathbf{1}$ şi $\mathbf{2}$ & $\mathbf{3}$ & $\mathbf{4}$ & \\
\hline \multirow{3}{*}{ Colesterol } & Normal & 12 & 31 & 4 & 47 \\
\cline { 2 - 6 } & $\%$ & $25,5 \%$ & $66,0 \%$ & $8,5 \%$ & $100,0 \%$ \\
\cline { 2 - 6 } & Crescut & 5 & 27 & 21 & 53 \\
\hline \multirow{3}{*}{ Total } & $\%$ & $9,4 \%$ & $50,9 \%$ & $39,6 \%$ & $100 \%$ \\
\hline
\end{tabular}

Utilizând testul Chi Square pătrat pentru a evalua influenţa nivelului colesterolului seric asupra treaptei terapeutice, am obţinut o corelaţie statistic semnificativă $(p<0,001)$ în sensul că pacienții la care s-au înregistrat valori crescute ale colesterolului corespundeau, într-un procent semnificativ, treptelor terapeutice 3 şi 4 . Aceste aspecte sunt ilustrate în figura 2 .

\section{DISCUȚII}

Rolului proinflamator al colesterolului seric asupra mucoasei bronșice la pacienții cu astm a suscitat un mare interes ştiințific în ultimii ani.

Cercetările existente în literatură care iau în studiu legătura dintre colesterol şi astm sunt în majoritate întreprinse la adulţi şi puţine la copii, cu rezultate contradictorii. 


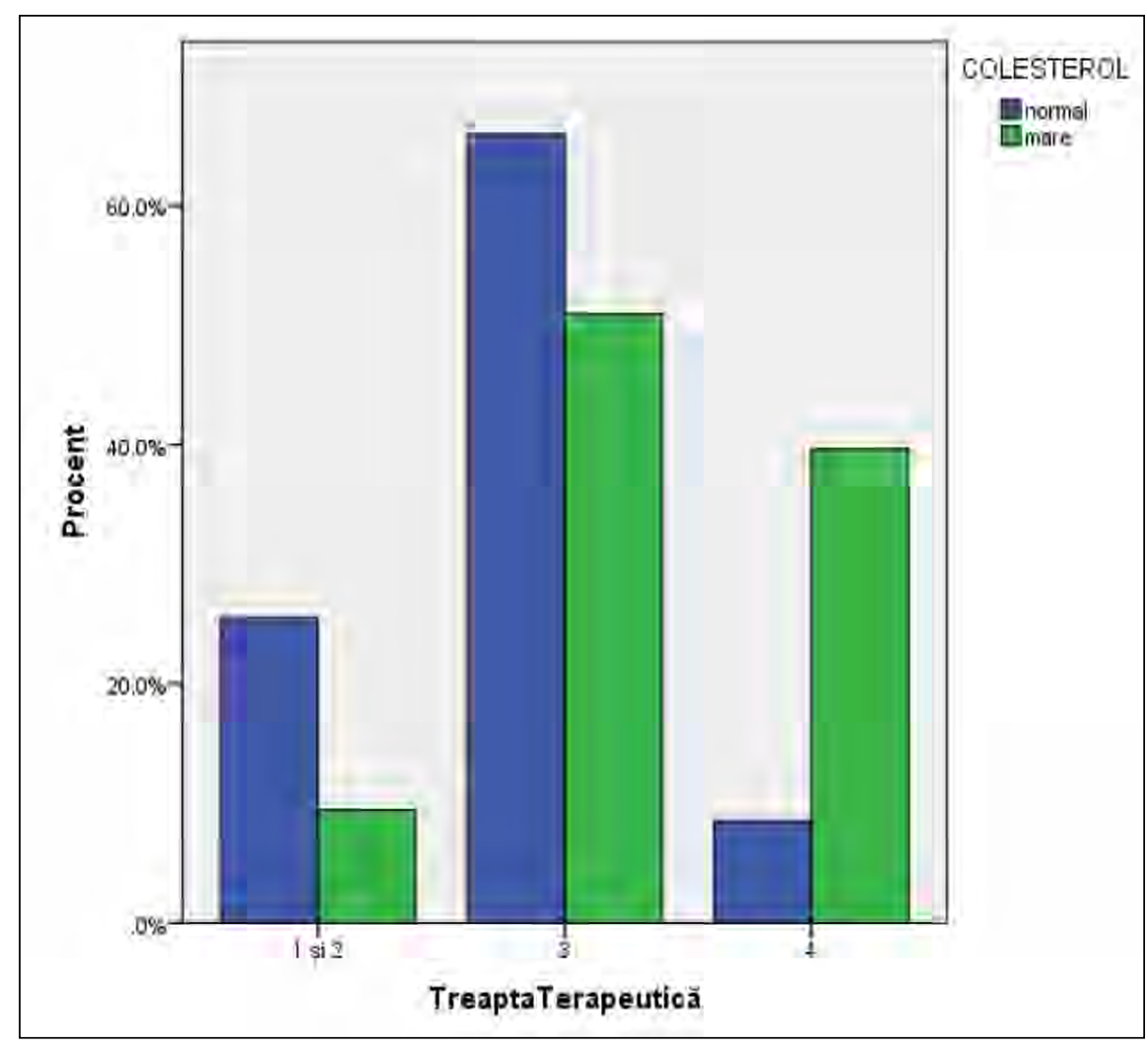

FIGURA 2. Distribuția procentuală a pacienților care aveau valori normale de colesterol, respectiv valori crescute şi încadrarea în treptele terapeutice
Astfel, într-un studiu efectuat de către Karthikeyan Ramaraju şi colaboratorii, publicat în 2013, s-a ajuns la concluzia că între astm și nivelul colesterolului seric există o asociere semnificativă, independent de sexul, vârsta, BMI sau nivelul socio-economic al pacientului (3).

Rebecca K. Vinding şi colaboratorii publică în 2016 în „The Journal of Allergy and Clinical Immunology", volumul 137, un articol în care susţin că hipercolesterolemia înclină sistemul imun adaptativ către răspunsul Th2, care poate afecta unii pacienţi cu boli precum astmul bronşic (8).

Într-o metaanaliză publicată în 2017 de către Su X și colaboratorii, efectuată pe 10 studii clinice privind asocierea dintre astm și nivelul seric al profilului lipidic, s-a concluzionat că pacienţii cu astm au nivelul colesterolului total mai mare faţă de cei nonastmatici (7).

Studiul asocierii dintre profilul lipidic sanguin şi astm ar putea deschide in viitor noi perspective asupra strategiilor de management al acestei afecţiuni $(1,2,8)$.

\section{CONCLUZII}

În lotul studiat, efectuat la copiii diagnosticaţi cu astm alergic și sensibilizare aeroalergenică, valoarea serică a colesterolului se poate asocia cu gradul de control al bolii.

De asemenea, în studiul efectuat, valoarea serică a colesterolului total se poate asocia cu treapta terapeutică.

Conflict of interest: none declared Financial support: none declared

\section{BIBLIOGRAFIE}

1. Jaewook Jeong, Myong Ki Baeg, Sun-Hye Ko. Lipid profiles in adolescents with and without asthma: Korea National Health and nutrition examination survey data. Lipids Health Dis. 2018 July; Vol 17: pp 158.

2. Chen YC, Su MW, Wang PC, Tsai CH, Tung KY. Lipid profiles in children with and without asthma: Interaction of asthma and obesity on hyperlipidemia. Diabetes Metabolism Syndrome 2013 Jan-Mar; Vol 7 (1): pp 20-5.

3. Ramaraju K, Krishnamurthy S, Maamidi S, Kaza AM, Balasubramaniam N. Is serum cholesterol a risk factor for asthma? Lung India 2013 Oct-Dec; Vol. 30, No.4, pp 295-301.

4. Lambrecht BN, Hammad H. The immunology of asthma. Nat Immunol. 2015 Jan; Vol. 16(1): pp 45-56.

5. Al-Shawwa B, Al-Huniti N, Titus G, Abu-Hasan M. Hypercholesterolemia is a potential risk factor for asthma. J Asthma. $2006 \mathrm{Apr}$; Vol 43(3): pp 231-3.

6. Global Strategy for Asthma Management and Prevention, Global Initiative for Asthma 2016.

7. Su X, Ren Y, Li M. Association between lipid profile and the prevalence of asthma: A meta-analysis and systemic review. Current Medical Research and Opinion. 2017 Nov 10: pp1-11.

8. Rebecca K Vinding, Jakob Stokholm. Blood lipid levels associate with childhood asthma, airway obstruction, bronchial hyperresponsiveness, and aeroallergen sensitization. The Journal of Allergy and Clinical Immunology 2016 January: Volume 137: pages 68-74. 